\title{
Central Asia, Afghanistan and International Order: Challenges and Opportunities of Shanghai Cooperation Organization
}

\author{
Kuralay Maksut
}

Published online: 13 December 2012

(C) CEEUN 2012

\begin{abstract}
At the present stage of globalization, most regional and local problems become transnational issues or even international conflicts, therefore regional partnerships and regional networks, including those involving governments, subregional and regional organizations are becoming crucial actors for implementing solutions of these conflicts. One of these multilateral security structures on the EurAsian continent is the Shanghai Cooperation Organization (SCO). Founded in 2001 originally as a political union of five countries-People's Republic of China, the Russian Federation, the Republic of Kazakhstan, the Kyrgyz Republic, the Republic of Tajikistan and the Republic of Uzbekistan; plus four observers Mongolia, India, Pakistan and Iran)_-aiming to settle the border issues of the former Soviet-Chinese border, today, the SCO has grown into a full-fledged multilateral framework. This paper brings a brief highlight on the factors contributing to stability and mutual beneficial projects in the region and the SCO measures to curb potential threats. But it also enlightens the uprising of a well known player in the region, Turkey, with its historic heritage but first of all with its contemporary mighty being at the same time a NATO top member and an official candidate for EU membership. The Spring in the whole Greater Middle East will have long lasting repercussion and impact on the wide and crucial EurAsian region
\end{abstract}

\footnotetext{
K. Maksut $(\bowtie)$

Former Eurasian National University, Astana, Kazakhstan e-mail: kuralay2002@gmail.com

K. Maksut

Comenius University, Bratislava, Slovakia

K. Maksut

Researcher Transition Studies Network, Rome/Venice, Italy
} 
Keywords International organization - International cooperation · Political dialogue · Afghanistan · Political interest · Development projects · Foreign politics · New actors in the EurAsian great region - Turkey

\section{Introduction}

After its establishment as an international organization, the Shanghai Cooperation Organization (SCO) has been followed in the early stage of its development with attention but skepticism while today it has gained attention more for the political contents than for the operative partnership that was limited to joint military exercises of minor relevance and some attempts to improve trade relations between the partners. Only upon closer examination cautions are emerging about the growing potential of the SCO. As it is well known, the vast majority of SCO member states as well as other Asian countries are involved in a number of territorial disputes and conflicts such as ethnic separatism and irredentism, strategic interests in the region, as well as geo-economic interests of world powers.

One quarter of the world oil reserves and production, one-third of gas reserves and almost half of the known reserves of uranium are located in the current SCO countries; therefore the risk of being dragged into conflicts over reserves and mines of such strategic raw materials is not far-fetched. Also the limited water resources could in the long term cause disputes and tensions in the region, not to mention the fact that one of the major threats is the destabilization of the situation in Afghanistan and the already imminent "exit" both of the USA armed forces and the NATO supported ISAF troops.

On this specific issue, of great interest appears the reading of the New York Review of Books issue of September 2012, in the first issue of the Journal of Global Policy and Governance, with the permission of the prestigious American intellectual magazine. In "Lessons from Afghanistan" Rory Stewart is reviewing a book by the author Diana Preston describing the preliminary strategic analyses and options of the Foreign Office in London, the divergent attitudes related to the British war to conquer the country between 1839 and 1842 held by the Foreign Secretary, Lord Palmerston, and Benjamin Disraeli, the prestigious future Prime Minister and Statesman who ridiculed the decision to conquer Kabul and Afghanistan as senseless, rising sharp polemics with the Prime Minister at that time, Sir Robert Peel.

On a bilateral basis many SCO states have programs for assistance and cooperation with Afghanistan. However, member countries do not have a unified position and high operational efficiency for a long-term stabilization of the situation in Afghanistan. We for our part have to wonder why politicians never care for modern and contemporary history and its lessons, repeating the same mistakes and paying the price in the form of defeats and waste of financial resources.

\section{Background}

The Shanghai Cooperation Organization is a permanent intergovernmental international organization founded on 15 June 2001 in Shanghai by the People's 
Republic of China, the Russian Federation, the Republic of Kazakhstan, the Kyrgyz Republic, the Republic of Tajikistan and the Republic of Uzbekistan. The four observer states are Mongolia, India, Pakistan and Iran.

The main goals of the SCO are strengthening mutual confidence and goodneighborly relations between the member countries; promoting effective cooperation in politics, trade and economy, science and technology, culture as well as education, energy, transportation, tourism, environmental protection and other fields; making joint efforts to maintain and ensure peace, security and stability in the region.

The Council of Heads of State Council (HSC) is the highest decision-making body in the SCO. It meets once a year to take decisions and give instructions on all important issues of the SCO activity.

The SCO member states occupy a territory of around 30 million 189 thousand square kilometers, which makes up three fifths of the EurAsian continent, and have a population of 1.5 billion, which makes up a quarter of the planet's population (Sectsco 2009).

\section{Contextualizing the Region}

Since the official creation of the SCO in June 2001 more than 10 years have passed. One of the important factors in creating the SCO was the situation in Afghanistan, in the Russian Federation itself and its position in Central Asia as well as the situation in the Xinjiang Uygur Autonomous Region (XUAR) in the eastern part of the People's Republic of China. A direct military and terrorist threat came from the Taliban regime, not only externally, but also internally as active radical movements exercised influence over disadvantaged groups in Central Asia, Russia and China. In addition to this the clandestine activities associated with the banned "Hizb ut-Tahrir" 1 and the "Islamic Movement of Turkestan", ${ }^{2}$ the previously unknown Islamist group Jund al-Khilafah ${ }^{3}$ acting in the Muslim regions of Russia and former Soviet states in Central Asia and in XUAR, as well as extremist organizations in the Northern Caucasus (Kadyrbaev 2011) increased. Recent activities of armed groups in Kazakhstan caused security concerns after two terrorist attacks in May when a suicide bomb attack took place against the Department of the National Security Committee (KNB) in Aktobe. On July 1 in the Aktobe region a full-scale armed conflict has begun. Jund al-Khilafah claimed responsibility for the October 2011 bombings in the city of Atyrau. Two police officers were shot dead in November in

\footnotetext{
${ }^{1}$ Hizb ut-Tahrir, or Party of Liberation is active in 40 countries, recruiting men and women in those countries as followers. In many countries authorities put Hizb ut-Tahrir and 14 other groups on a list of banned terrorist organizations (Kamalov 2011).

2 According to the information of special agencies the Islamic Movement of Turkestan is a fictional invention created by the Uzbekistan SNB (Council of National Security) in order to suggest that this organization intends to re-establish a Turkestan and create problems for all countries in Central Asia, whereas its actual activities are only focused against the present leadership of Uzbekistan.

3 Jund al Khilafah, or Soldiers of the Caliphate, is an al Qaeda and Haqqani Network-linked terror group that is based along the Afghan-Pakistan border.
} 
Almaty by unidentified assailants and an armed person killed seven people, including five security forces, and then shot himself in city Taraz (Shestakov 2011) in November. The Afghan crisis and its many manifestations such as social and political instability, terrorism, as well as the import of terrorism and drug trafficking, ${ }^{4}$ weapons sales, transnational crime are now the main source of destabilization of the situation in the SCO region. The geographical position in Central Asia is a core element of strategic considerations of the SCO as current terrorist and other illicit activities are threatening the security of the entire region.

Experts have already declared that the situation in the SCO area in the coming years will largely depend on the further development of the military-political situation in the Islamic Republic of Afghanistan (IRA) and the Pakistani borderlands (Academy of geopolitical issues 2011).

The SCO member states concluded an agreement on establishing a regional antiterrorist structure in Central Asia, which is primarily a response to the events that took place then in Afghanistan. More or less, these documents provided opportunities for the formation of permanent bodies of the regional organization. However, still to this day little is known about the SCO as an effective mechanism of interaction that is capable of solving problems in the Central Asian region, especially concerning the issues of security and stability.

One significant thing that cannot be missed in all these joint declarations and statements is the repeated emphasis on "strategic" and "cooperation". China and Russia have endorsed their strategic components in the region but only in general terms (Čech 2007; National Security Strategy of Russian Federation 2012).

As Russian scholar, Y. Solozobov observes that “... the SCO is one of China's main foreign policy instruments for the expansion in the former Soviet Central Asia. The confidence of Beijing in its leadership role in the SCO due to the growing Chinese economic and military potential far exceeds the activities of SCO partners. For example, recently in the framework of the SCO on the initiative of Beijing loans were established which have been used in Kyrgyzstan, Tajikistan, and Uzbekistan" (Solozobov 2012).

But China has a moderate attitude towards upgrading priorities and the SCO since its existence has not been constant. While the first summit of the member states in 2001 was largely under the auspices of the issues of security in the region, in the meantime regional economic co-operation has emerged as the most promising trend. It is the first time that the organization seems to be set exclusively towards the economy and nothing can prevent its further evolution into becoming a regional and political forum. Yet the events of September 11, 2001 in the United States, the American intervention in Afghanistan and the emergence of these events as a result of US military bases in Central Asia have not only changed the geopolitical balance of power in the region but also the preferences of SCO member states. It should be emphasized that so far none of the Member States officially has made statements contradictory to the agreements made by them earlier during the official meetings of

\footnotetext{
4 Today Afghanistan produces more than $90 \%$ of opiates in the world. In 2010, law enforcement and intelligence agencies of the Russian Federation from illegal trafficking confiscated over 49 tons of narcotic drugs and psychotropic substances. The annual income of drug cartels which supply drugs via the Northern route from Afghanistan to Russia amounts to 15 billion dollars.
} 
Representatives at different levels in recent years. Nevertheless, some cooling of relations between member countries has became manifest, as the situation in Central Asia began to take shape in such a way that the vision and approaches of Russia and China to ensuring regional security in Central Asia are increasingly competing with those pursued by the USA, European Union, Turkey and of course NATO which for years have been present in the region in political terms but also with security and strategic options. Under these circumstances in the eyes of the heads of the Central Asian states the SCO regional security system has somehow faded away, while its perspective is assessed not in terms of those common to all current threats to Central Asian states, but based on the characteristics of the individual collaboration of particular states directly with Russia, China, the United States, the European Union and Turkey. Taking into account the continuing concerns about the "imperial ambitions" of Russia, the fear of "Chinese expansion" shared by certain ruling circles of the Central Asian states, and the US and European promises of investments in view of the "exit" strategy from Afghanistan but not from Central Asia, the change of positions or the tendency to change of the above mentioned countries is quite clear.

However, the countries of Central Asia within the SCO and outside the organization are still more closely linked with Russia than with China, in economic, ${ }^{5}$ military, political as well as in cultural terms. After its end the former Soviet Union had left some heritages. For example on the territory of the Republic of Kazakhstan, Russian troops are stationed in Baikonur cosmodrome and the missile range Saryshagan. The Russian Federation, Kazakhstan, Kyrgyzstan and Tajikistan have a common air defense system, not to mention the fact that these countries are members of the Collective Security in Central Asia. ${ }^{6}$ In Kyrgyzstan there is the Russian air base ${ }^{7}$ in Kant; in Tajikistan the Russian division- $201^{8}$ is stationed (ITAR-TASS 2011). After the appearance of US bases in Central Asia the SCO is facing the problem of cooperation in the anti-terrorist coalition leading the military actions against the Taliban. SCO (with a very cautious approach of China) and NATO countries are now cooperating for the first time ever. However the problem of solving the seemingly simple task of ensuring security in the region has in fact different angles. At the same time SCO and NATO pursue opposite goals which may lead to further frictions of the situation in Central Asia. There are various ways to assess the significance of the US military presence in Central Asia, but the presumption that the goals might be not only a confrontation with Russia and

\footnotetext{
5 Resent example of economic cooperation is The Customs Union (Russian Federation, Kazakhstan and Belarus).

6 The Collective Security Treaty Organization (CSTO), formed under the framework of the Commonwealth of Independent States. CSTO members are Russia, Armenia, Belarus, Kazakhstan, Kyrgyzstan, and Tajikistan.

7 In accordance with a bilateral agreement between Russia and Kyrgyzstan signed on 22 September 2003, the air base hosts Russian Air Force units. In 2009, the agreement was extended for another 49 years, with possible extension for another 25 years.

8 In 2004 the division was transformed to the 201st Military base. In June 2009 in connection the base was transferred to the state of standard infantry brigade (the battalion in Kulyab, Kurgan-Tube, Dushanbe).
} 
security in the region, ${ }^{9}$ but also the creation of a springboard in anticipation of future confrontations with China appear more than remote and not in the strategic agenda of these main powers. For sure Turkey will assume a more active role in the region and that means also a concrete NATO presence via Turkey that in the meantime has turned into a cornerstone of the security and military options in the entire Middle East and EurAsian region.

The expansion of the influence of the Taliban in the Afghan provinces bordering the Central Asian countries increases the conflicts threatening the security of the SCO. There are active operations of al-Qaida and similar forces establishing training camps, hideouts and military bases in north-eastern Afghanistan along the border with Pakistan, even if the terrorist organization lead by Osama Bin Laden has lost almost all its strategic relevance after US special forces, with the diffused perception of a covert, decisive cooperation of the Pakistan intelligence, brought to the blitz and elimination of the mastermind of the shocking terror attack on the Twin Towers on September 11 in New York.

The current activities are of course a preparation of the more radical organizations for the time of the withdrawal of US and NATO troops, when responsibility for security in IRA will pass to Afghan security forces (the process will likely take more time than expected and many doubts are mounting on the effectiveness of the control of the territory). ${ }^{10}$

The borders with Afghanistan are poorly controlled. The drug trade in this region is part of the picture of instability, especially as it provides income and transit routes for Taliban and other extremist groups. The porous Tajik-Afghan border made Tajikistan a major transit point for transporting Afghan heroin to Russia and Europe. Other routes are via the Uzbek-Afghan and Turkmen-Afghan borders. According to a UN report, in 2011, opium in Afghanistan was planted on 131 hectares, which is a $7 \%$ increase against he previous year. The quantity of opium produced has increased by $61 \%$ from 3.6 tons in 2010 to 5.8 tons in 2011. A diffusion facilitated by the number of Afghani refuges in Iran and Pakistan already numbering some millions that 1 day will return to their homeland.

In general the conflict in Afghanistan and the threats emanating from the country are forcing the states in the region to take additional measures to enhance security, diverting resources needed to address socio-economic problems and the implementation of development plans, the transit potential and modernization of the region (Dubovitskii 2011). SCO is not and will not become a military union; however, the protection of regional security is an important task of the organization. The creation of the common strategy has been dictated by the need to counter the "three evil forces" (terrorism, separatism and extremism). In 10 years, SCO has conducted more than 10 military exercises jointly leading the fight against drug trafficking and

\footnotetext{
9 An unexpected visit of US State Secretary to Afghanistan was made on October 19, 2011. The visit, which was not known in advance, included a meeting with the Afghan President Hamid Karzai. The purpose of the visit of the US secretary of state in Kabul was the search for ways to a "diplomatic solution" in Afghanistan, the need for which Clinton announced earlier.

10 In September 2011 an assault by Taliban insurgents in the heart of Kabul's diplomatic and military enclave ended after $20 \mathrm{~h}$ when large number of security forces could not resist the six attackers, a very telling event to be considered in this kind of "non conventional" conflicts.
} 
transnational organized crime, as well as launched a new cooperation in such spheres as the fight against money laundering, the maintenance of security in largescale international events (Kazinform 2011) and create a Contact Group (CG) of the SCO-Afghanistan.

The situation in the IRA requires joint monitoring with the participation of Afghan representatives. This activity should involve partners and observers of the SCO. In particular, India is offering to share with the countries of the SCO its rich experience in this field. India also expressed its wish to cooperate with the RCTS ${ }^{11}$ supporting Afghan responsibility for their own safety. But it is difficult to estimate the RCTS contribution to the fight against terrorism, separatism and extremism and then Pakistan is a regional power antagonist to India.

\section{Cooperation at Regional Level}

All SCO members are stating clearly that it is impossible to solve the Afghan problem relying solely on military activities. There is the need to change the fundamental approaches to the evaluation of the Afghan crisis and to focus on the search for peaceful ways of resolving the conflict through long-term policies to create sustainable economic and social basis of the development of IRA. Otherwise, the victory will be gained by the ultimately radical supporters of armed conflicts, which will be based in Central Asia. Political, diplomatic and economic assistance is the foundation of a wise settlement of the situation in Afghanistan.

Today cooperation at the regional level pays a key role and is the only viable policy to keep in contact the neighboring countries and Afghanistan. As neighboring states are most affected by the problems caused by the Afghan conflict they are interested more than others in stabilizing the situation and bringing peace to IRA. Their positive and active action will be targeted to achieve solid external conditions for the Afghan national reconciliation. It is obvious that a very active participation of neighboring countries in stabilizing Afghanistan is required by building infrastructure and creating new conditions for the settlement of social programs for people in the medical field.

Regional cooperation and economic integration of Afghanistan with other countries in Southern and Central Asia should be promoted. In particular, Chinese enterprises are already operating successfully in Afghanistan carrying out in this country a significant investment. In 2008, the Chinese corporation Metallurgical Corp of China's assured the largest copper mine Aynak in Logar province. On December 28, 2011 in Kabul, the Afghan Government signed a contract with China National Petroleum Corporation (CNPC) to develop oil fields in the Amu Darya basin.

India contributes to the creation of infrastructure, providing qualified staff such as doctors and engineers. India is interested in the long-term stability of Afghanistan and has invested $\$ 1.2$ billion in various projects of the IRA. In 2010 (just after the

\footnotetext{
11 The Regional counter-terrorist structure (RCTS) is a permanent acting agency of Shanghai Cooperation Organization (SCO).
} 
signing of the Delhi and Kabul agreement on strategic partnership), a consortium of Indian AFISCO got control of a significant portion of iron ore deposits in the central Hajigak province of Bamiyan. Reserves are estimated at 1.8 billion tons, which is sufficient to meet the 6 million tons capacity steel manufacturing plant's requirements for over four decades.

Iran is starting a company to create and develop mineral deposits in Afghanistan and is already building the transport infrastructure.

Particularly promising strategic projects are the development of transport communications, passing from the Central Asian region through Afghanistan to the South of Asia. Uzbekistan participates in building railroads, bridges and social facilities in the northern Afghan regions, which have improved the condition of the road infrastructure. The Afghan transport system is increasingly integrated with the Uzbek transport communications. In December 2011 at the newly constructed railroad Hairaton-Mazar-e-Sharif the first train started to connect the northern border of the country. "This is a welcome development which should facilitate the transport of supplies to Afghanistan, and contributes to the development of trade relations in the region. The train arrived without a load on the newly constructed station in Mazari-Sharif after a 75-km distance from the border with Uzbekistan", told the deputy minister of public works Afghanistan Noor Gul Mangal, who oversaw the project.

The railway is the first step in an ambitious project that will link Afghanistan with the neighboring countries and pave the way for the development of trade relations between Europe and Asia. IRA never had a functioning railway (Kolektív autorov 1989), since projects have been abandoned for various reasons, but the civil war of recent decades has made it impossible to build railways (Čech 2000). In the short term the railway will help to relieve the internal terminal port Khairaton. "This terminal is one of the main points of international trade, so it is very important", said the Head of Central and West Asia, the Asian Development Bank Juan Miranda, who financed the project worth 165 million dollars. Railway communication will increase the capacity of the terminal with 4,000 to 25,000-40,000 tons of cargo per month. From Mazar cargo can be delivered anywhere in Afghanistan. Commercial shipping on the route will be provided by the Uzbek Company "SE Sogdiana Trans", said a representative of the Asian Development Bank Noriko Sato. Uzbekistan also supplies electricity for the power line, built by India. The city of Kabul and its surrounding area are provided with electricity supply from Uzbekistan. But Afghan businessmen opposed the monopoly of the Uzbek Company to commercial traffic. Afghan authorities claim that the agreement with the Uzbek side has a temporary nature and will be reviewed.

Due to the geographical position Afghanistan has the potential of becoming a trade, energy and transport hub of the region that will promote its long-term sustainable development. It could also become an important hub connecting the Middle East and Southeast Asia in the network passing through a corridor (Slovak Foreign Policy Guidelines, MFA SR 2011). Creating a Trans-Afghan corridor by constructing new railways to connect cities in IRA, Uzbekistan, Iran, and Pakistan will carry freight coming from Southeast Asia to Europe. This is shorter than passing through Far Eastern rail corridors and generally will expand the transport and communications and transit opportunities of the region. 
Kazakhstani expert Dosym Satbayev has stated that Uzbekistan is interested to expand the zone of influence in Afghanistan, because it is in its vital interests. Such attempts on the part of Tashkent were made before, when it supported the Afghan warlord general Abdul Rashid Dostum, an ethnic Uzbek.

As for Turkmenistan, Ashgabat is taking interest in Afghanistan as a country through which to implement the transit of natural gas. The history of this interest goes back to the 1990s of the last century, when the gas pipeline project from Turkmenistan through Afghanistan to Pakistan and beyond, through which Turkmen gas will flow, not only was lobbied by Ashgabat but also by United States (Čech 2011).

According to the press service of the government of Turkmenistan, at the final meeting between the Turkmen and the Afghan side issues of strengthening stability and economic development of IRA, the expansion of cooperation in the region in transport transit, agriculture and power generation were discussed "at the meetings that pointed out the value of a number of projects initiated by Turkmenistan, in particular the TAPI gas pipeline and the railway Atamyrat-Imamnazar-AkinAndhoy and the construction of a power line rail Mary-Atamyrat-Andhoy. This would increase the export of electricity to Afghanistan five times and meet $70 \%$ of the neighboring country's electricity needs", said a statement the representative of the Government of Turkmenistan.

Tajikistan also supplies electrical power in small amounts to the Afghan city of Kunduz. However, chronic problems with Uzbekistan, such as the mutual personal dislike of the two presidents, impair Tajik trade, energy self-sufficiency and economic development. Afghan fighters could threaten the security of Tajikistan through a long and transparent border. Another issue is a major hydroelectric dam in Tajikistan which is controlled by Russia; the dam has now become a source of contention between the two countries.

Unlike Turkmenistan, Tajikistan and Kyrgyzstan are more interested to promote infrastructure projects. In this connection the CASA-1000 project should be mentioned, with the construction of a power line from Kyrgyzstan and Tajikistan to Afghanistan and Pakistan (Satbayev 2011).

Kazakhstan also constructed factories and will continue to provide humanitarian assistance to Afghanistan, supplying grain, flour, rice and other goods. The government of the Republic of Kazakhstan provided $\$ 2.3$ million for building schools, hospitals and roads in Afghanistan. Since 2010, every year up to 200 Afghan students come to study in Kazakhstan. A total of 1,000 Afghan students will get education as doctors and teachers at Kazakh universities under a special 50 million dollar program that runs from 2010 to 2018. "Afghanistan's socio-economic rehabilitation is an essential guarantee of regional and international security and stability," told the Kazakh Foreign Minister Yerzhan Kazykhanov participants of the Istanbul conference on Afghanistan in Istanbul as he pledged Astana's continued support for more robust international efforts to assist that country return to the peaceful life (MFA of RK 2011).

According to MFA of RK, Kazakhstan supports the New Silk Road initiative for creating infrastructure such as roads and rail lines to link Afghanistan with its neighbors also by building Kazakhstan's portion of an international highway corridor that will connect Western China with Western Europe through Russia. 


\section{Ethnic Issues}

In addition to the socio-economic issues the ethnic question needs to be addressed. Without it a long-term stabilization of Afghanistan is not feasible. Solving the problem in Afghanistan is impossible without inter-state cooperation on security. The SCO countries recognize the UN's leading role in resolving the situation in Afghanistan and in promoting the peaceful restoration. The organization of the negotiating process should be carried out under UN auspices. The United Nations might be the only effective mechanism for international cooperation, capable of providing security and promoting economic development.

In one word, the situation in the SCO member countries depends on the evolving situation in Afghanistan. Therefore, the new perspective of the situation in Central Asia will be determined by the conclusion of the withdrawal of US and NATO troops from Afghanistan. This event, already in advanced operative development, requires a clear vision of the SCO forms and methods of cooperative security in its area. The Taliban represent the interests of many national tribes, so there is a danger that without the support of the Western coalition, the secular Afghan government will not be able to stay in power, as the current state of the Afghan security forces is completely unsatisfactory. The previous adventure of Russia in the country shows the situation that could soon again occur (Oshanin 2004).

The US first sent a representative to the ongoing SCO international conference on Afghanistan in 2009 where an action plan called on Member States to cooperate with international actors, including NATO, to fight drug trafficking, strengthening defense and developing the economy of Afghanistan. In 2010, for the first time, representatives of the Russian drug police took part in the successful raid carried out jointly by NATO and Afghan forces against drug laboratories in Afghanistan.

Creating a closer relationship may provide dialogue partner status with the SCO, the application for which official Washington sent in 2011. It will help the US to work on countering extremist organizations in the EurAsian region.

These issues were very much present during the SCO anniversary Summit that took place in Astana on 14-15 June 2011, chaired by the President of the Republic of Kazakhstan N. Nazarbayev, the Chairman of the People's Republic of China Hu Jintao and all the President of the other member countries. In 2011, Afghanistan had requested observer status in the SCO. It should continue the practice of inviting the Afghan leaders to the summits of Heads of SCO Member States as guests of honor but negotiations are for granting the observer status to Afghanistan are still at the beginning (Joint Communiqué of meeting of the Council of the Heads of the Member States of the SCO 2011).

One important task for the Central Asian region and the world community is to reverse the perception of Afghans of the outside world as hostile. This is impossible without respect for the historical, ethnic and demographic characteristics of Afghanistan, centuries-old customs, which are followed by the multinational and multi-confessional people of Afghanistan.

China will end its term of chairmanship the Shanghai Cooperative Organization in 2012 . 
The member states called for further expansion of cooperation with the SCO observer states-India, Iran, Mongolia and Pakistan, the dialogue partners-Belarus and Sri Lanka whose potential can give significant impetus to further developments.

\section{Concluding Remarks: Challenges Ahead and Turkey's Role in Central Asia}

Afghanistan has great geopolitical importance for EurAsia. The SCO for years has played an important role in the region, but today, as the world is changing, the goals and objectives are also expanding as regards for instance, cross-border crimes, drug trafficking and other threats.

For a reliable perspective of peaceful reconstruction of Afghanistan-after the long wars of the last 40 years with the defeat of Russia before and almost the same experience of the US and NATO in the last ten years of military conflict, it is necessary to establish more effective relations with Pakistan. In countries like China and India there is a number of unresolved issues related to common border and territorial disputes. In these matters the example of successfully developing bilateral relations of China and India, despite the existing problems might be very interesting. Pakistan has great potential in the economic and political sphere, in addition, it has a significant impact on the political situation in Afghanistan, the fight against extremism and drug trafficking.

As well as many other countries China seeks to build a strong relationship with IRA. India traditionally has good relations with the IRA, while forging bilateral relations are not within the SCO. Russia can play a key role in balancing the interests of New Delhi and Beijing and, thus, more closely involve Afghanistan in the SCO.

The interaction between Russia-China-India-Pakistan on Afghanistan might help solve the common problem and get out of deadlock, reducing the influence of the Taliban and the too many safe heavens they have in the bordering countries.

NATO's decisions to transfer security responsibility to Afghan security forces by 2014 will be a big challenge and the moment of truth for the SCO and the CSTO. Therefore, according to experts, now the SCO members as well as CIS countries are taking all necessary efforts to ensure the partner countries a capability of selfconfrontation to growing threats.

But as underlined in the abstract and before mentioned, a new competitive and mighty actor is emerging and entering the stage of the EurAsia macro-region: Turkey. Not by caressing antique "nostalgias" for the Ottoman era but as a worldwide emerging power, already outperforming Central Asia in the economic, financial, industrial, trade, strategic and logistic sector; de facto, independent thinktanks data, international organizations reporting and foreign policy of Ankara had enlighten already the character of permanent main protagonist in this part of the world (Rubin and Kirisci 2001). The Syria "affair" has remembered all the parties that NATO article 5 is pending (providing that the military threat to one member of the Alliance will encounter the reaction of all NATO military capabilities) on those threatening the security of the Country, while the Hague Court is waiting for the responsible of the bloody civil war to be indicted and judged on their 
responsibilities. The European Union is re-starting the enlargement process in Southeast Europe and next June Croatia will become a new member, probably soon followed by Montenegro and Macedonia, while Serbia and Bosnia-Herzegovina will follow some years later. The Balkan has changed the geopolitical perspective of Turkey and Europe. Istanbul is a crucial capital of the global economy and finance, a hub for trade, business and air transports. Who flies from Central Asia has to relay mainly Turkish Airlines timetables. These events will bring the entire region out of its isolation and not only oil and gas but technologies, environment policies, human capital enhancement, foreign direct investments in non oil sectors will be growing at high rates as already seen in the last years. The international community starts now to perceive these new events and emerging power conditionality in the full region and in the whole Middle East. A perspective opening options and developments is already on the table of the main decision making powers. Washington of course but also Moscow, Beijing, London, Paris, Berlin, Cairo, Teheran and of course Tel Aviv for the unresolved long-cherished and firmly pursued Palestinian expectation of two states two territories, also based on precise UN resolutions.

The next 20 years will determine great evolutions and hopefully peaceful solutions to the long lasting conflicts and tensions in this part of the world. The wave of the North Africa Spring is only a first beginning of a change and reform process in the all Islamic world, the Green Belt going from Morocco to Indonesia. The next events will be much more crucial to the global governance not only in Central Asia.

\section{References}

Academy of geopolitical issues (2011). http://akademiagp.ru/. Accessed 27 Dec 2011

Čech L (2000) Phenomenon of Islamic fundamentalism. Securitologia-Zeszyty Naukowe European Association for Security. Poland: Czasopismo nauk o bezpieczeňstwie. European Association for Security

Čech L (2007) Afghanistan-facts and context. Science and military, No. 2. Liptovský Mikuláš: Akadémia ozbrojených síl generála M.R. Štefánika

Čech L (2011) Central Asia and the main factors of the conditional stability of the region. Banská Bystrica: Zborník príspevkov zo IV. medzinárodnej vedeckej konferencie „Bezpečnostné fórum 2011 “. Fakulta politických vied a medzinárodných vžtahov

Dubovitskii V (2011) American fate in Afghanistan: from "A" to "Z". http://www.afghanistan.ru/ doc/19795.html. Accessed 15 Dec 2011

ITAR-TASS (2011) Russia supplied Afghanistan its first Mi-17V5. http://lenta.ru/news/2011/12/ 29/mi17v5/. Accessed 11 Jan 2012

Joint Communiqué of meeting of the Council of the Heads of the Member States of the SCO (2011). http://www.sectsco.org/RU/. Accessed 3 Dec 2011

Kadyrbaev A (2011) The influence of the Afghan factor for the leading countries of the SCO. http://www.afghanistan.ru/doc/20882.html. Accessed 9 Dec 2011

Kamalov E (2011) Hizb ut-Tahrir recruiting young women. http://centralasiaonline.com/en_GB/ articles/caii/features/main/2011/09/26/feature-01. Accessed 10 January 2012

Kazinform (2011) Kazakhstan has made significant contributions to the development of good neighborly relations, mutual understanding and constructive partnership. http://www.inform.kz/rus/article/ 2427663. Accessed 3 Jan 2012

Kolektív autorov (1989) Evropská politika a východní horizonty NSR. Otázky a odpovědi. Ústav mezinárodních vztahů. Praha 
MFA of the Republic of Kazakhstan weekly publication of the MFA (2011). http://portal.mfa.kz/ portal/page/portal/mfa/en. Accessed 9 Jan 2012

National Security Strategy of Russian Federation. (The Strategy of National Security of the Russian Federation-2020). http://www.scrf.gov.ru/documents/99.html. Accessed 3 Jan 2012

Oshanin D (2004) The Afghan factor in Central Asia, Moscow

Rubin B, Kirisci K (2001) Turkey in world politics: an emerging multiregional power. Lynne Rienner Publishers, Boulder

Satbayev D (2011) Central Asia-Afghanistan: infrastructure projects and the prospects for integration. http://iwpr.net/ru/report-news/. Accessed 3 Jan 2012

Sectsco (2009). http://www.sectsco.org/RU/. Accessed 14 Jan 2012

Shestakov V (2011) Soldiers of the Caliphate in Kazakhstan. http://www.centrasia.ru/newsA.php?st= 1322807220. Accessed 5 Dec 2011

Slovak Foreign Policy Guidelines, MFA SR (2011) The EU and Central Asia: strategy for a new partnership, EC 2007-2013 regional assistance strategy

Solozobov Y. SCO —a Chinese master key for Central Asia. http://www.russian.kiev.ua/print. php?id=11605829. Accessed 4 Jan 2012 